\title{
Future distribution of invasive weed species across the major road network in the state of Montana, USA
}

\author{
Arjun Adhikari $^{1,2} \cdot$ Lisa J. Rew ${ }^{3} \cdot$ Kumar P. Mainali $^{4,5} \cdot$ Subodh Adhikari ${ }^{6} \cdot$ Bruce D. Maxwell $^{7}$
}

Received: 12 October 2019 / Accepted: 3 April 2020 / Published online: 12 May 2020

(C) The Author(s) 2020

\begin{abstract}
Invasive plant species are a significant global problem, with the potential to alter structure and function of ecosystems and cause economic damage to managed landscapes. An effective course of action to reduce the spread of invasive plant species is to identify potential habitat incorporating changing climate scenarios. In this study, we used a suite of species distribution models (SDMs) to project habitat suitability of the eleven most abundant invasive weed species across road networks of Montana, USA, under current (2005) conditions and future (2040) projected climates. We found high agreement between different model predictions for most species. Among the environmental predictors, February minimum temperature, monthly precipitation, solar radiation, and December vapor pressure deficit accounted for the most variation in projecting habitat suitability for most of the invasive weed species. The model projected that habitat suitability along roadsides would expand for seven species ranging from +5 to $+647 \%$ and decline for four species ranging from -11 to $-88 \%$ under high representative concentration pathway (RCP 8.5) greenhouse gas (GHG) trajectory. When compared with current distribution, the ensemble model projected the highest expansion habitat suitability with six-fold increase for St. John's Wort (Hypericum perforatum), whereas habitat suitability of leafy spurge (Euphorbia esula) was reduced by $-88 \%$. Our study highlights the roadside areas that are currently most invaded by our eleven target species across 55 counties of Montana, and how this will change with climate. We conclude that the projected range shift of invasive weeds challenges the status quo, and requires greater investment in detection and monitoring to prevent expansion. Though our study focuses across road networks of a specific region, we expect our approach will be globally applicable as the predictions reflect fundamental ecological processes.
\end{abstract}

Keywords Habitat suitability $\cdot$ Invasive weed species $\cdot$ Road network $\cdot$ Species distribution model

Communicated by Wolfgang Cramer

Electronic supplementary material The online version of this article (https://doi.org/10.1007/s10113-020-01647-0) contains supplementary material, which is available to authorized users.

Arjun Adhikari

arjun.adhikari@okstate.edu

Lisa J. Rew

lrew@montana.edu

Kumar P. Mainali

kpmainali@gmail.com

Subodh Adhikari

subodh.adhikari1@gmail.com

Bruce D. Maxwell

bmax@montana.edu

1 Department of Ecology, Montana State University, 310 Lewis Hall, Bozeman, MT 59717, USA
2 Natural Resource Ecology and Management, Oklahoma State University, 008C Agricultural Hall, Stillwater, OK 74078, USA

3 Department of Land Resources and Environmental Sciences, Montana State University, Bozeman 59717, USA

4 Conservation Innovation Center, Chesapeake Conservancy, Annapolis, MD 21401, USA

5 National Socio-Environmental Synthesis Center (SESYNC), University of Maryland, 1 Park P1 Suite 300, Annapolis, MD 21401, USA

6 Department of Entomology, Plant Pathology and Nematology, University of Idaho, 875 Perimeter Drive MS 2329, Moscow, ID 83844-2329, USA

7 Montana Institute on Ecosystems, Montana State University, 605 Leon Johnson Hall, Bozeman, MT 59717, USA 


\section{Introduction}

Ecological integrity and biodiversity of many ecosystems have been seriously threatened by expansion of invasive species (Pimentel et al. 2005). Invasive plant species are a significant problem with their potential roles in displacing native species, altering structure and function of ecosystems, disrupting natural and agricultural landscapes, and causing economic damage (Huston 2004; Fridley et al. 2007). Invading plants can reduce the amount of light, water, nutrients, and space available to native species and alter hydrological patterns, soil chemistry, moisture-holding capacity, erodibility, and change fire regimes where they invade (Vitousek et al. 1997; Mooney and Cleland 2001; Skurski et al. 2014; Van Kleunen et al. 2015). There is a great concern about the problems posed by invasive species in natural ecosystems globally, and the rates of invasive species establishment have increased with globalization and elevated warming (Huston 2004; Wilson et al. 2009; Williams et al. 2015). Both experimental and observational studies indicate biological invasions as a major threat to existing biodiversity, second only to landuse change as a cause of species endangerment (Bellard et al. 2016).

Predicting the occurrence of invasive species under current and future climate scenarios can help direct prioritization of species and locations to target for early detection and rapid response, focus toward best preventative approaches, and consider all essential components of effective invasive species management (Rew et al. 2007; Maxwell et al. 2009; Fournier et al. 2019). Strategies and policy for efficient assessment and optimum management largely depends on the ability to locate invasive species. Being able to accurately predict individual species' potential habitats over large landscapes can help streamline the management process by focusing on portions of management areas where species have a high probability of occurrence. The species distribution modeling (SDM) approach is a well-developed technique to project the habitat suitability range of native and invasive species based on their distribution relative to climatic and environmental factors (Guisan and Thuiller 2005; Elith et al. 2006). The technique has become an essential tool in ecology, biogeography, species conservation, and natural resource management (Franklin 2013; Hansen and Phillips 2015; Adhikari et al. 2019a). In this paper, we project habitat suitability of eleven noxious invasive weed species we observed across road networks of Montana, USA, under current and future projected climate (Whitlock et al. 2017).

Development, maintenance, and expansion of transportation corridors and other human activities create primary vectors for the introduction, establishment, and spread of invasive weeds. Roads can promote weed invasions in environments where they might not otherwise be competitive (Tikka et al. 2001; Gelbard and Belnap 2003; Veldman and Putz 2010;
Benedetti and Morelli 2017; McDougall et al. 2018). Since roads are known to be important dispersal corridors for weeds (Spellerberg 1998; Gelbard and Belnap 2003; Rew et al. 2018), invasive weed occurrence has been correlated with proximity to road networks (Spellerberg 1998; Pauchard et al. 2003; Rew et al. 2005; McDougall et al. 2018). Seed dispersal by vehicles (Rew et al. 2018) coupled with high frequency of disturbance immediately adjacent to rights-ofway translates to a more suitable habitat for ruderal and disturbance frequenting species. Once invasive species become established along roads, they can become the source for invasion into adjacent agricultural and wildlands, disrupting ecological processes, and interfering with agricultural productions (Vitousek et al. 1997; Walker and Steffen 1997; Dostálek et al. 2016; McDougall et al. 2018). Therefore, roads represent a distinct challenge for land managers because they pose a high risk for the introduction, establishment, and spread of invasive weed species.

From both management and ecological perspectives, roadside plant communities can be considered distinct ecosystems of spatially separated habitats in much the same way as riparian corridors because they occupy physical space, have a unique structure, support a specialized biota, exchange matter, and energy with other ecosystems, and experience temporal changes (Lugo and Gucinski 2000). Roadsides provide a unique environment throughout the length of the corridor, thus providing a conduit along which plant populations can establish and spread (Dostálek et al. 2016). Environmental conditions along roadsides can differ from previously existing conditions in terms of altered light availability, soil texture, compaction and chemistry, increased water runoff, and repeated disturbance from maintenance and off-road driving (D'Antonio and Vitousek 1992; Hobbins and Huenneke 1992; Gelbard and Belnap 2003; Rejmánek et al. 2013).

It has been estimated that the state of Montana spent \$27 million on invasive species control and management in 2015 (MISAC 2016), much of which was targeting noxious weeds. The most effective course of action is to detect invasive populations by identifying potential habitats for individual species under current and future environments with widely available data. All Departments of Transportations in the USA are required to control weeds along their road network and maintain records where they treat or identify specific species. Predicting likely areas of invasive weed species occurrence could be used to help detect new populations and manage them before the infestation grows, significantly reduce the cost of management (Rejmánek and Pitcairn 2002; Maxwell et al. 2009). Therefore, an early warning approach is essential in the prevention of known invasive species expanding into adjacent areas and the introduction of new invasive species, which can be achieved by projecting potential habitat range of these species. A number of modeling techniques (e.g., generalized linear model, decision tree, random forest, generalized 
additive model, and Maxent) have been found effective in predicting potential range of species under multiple scenarios (see Elith et al. 2006). These models can be developed with species' presence/absence or only presence data from multiple sources including research survey, museum, herbarium records, and inventories of species for a particular location along with different environmental climate predictors; but to make them useful to local managers, predictions need to be at an ecologically appropriate spatial resolution $(\leq 1 \mathrm{~km})$. The overall objective of this work is to assess projected habitat suitability of 11 invasive weed species under current and future climate. The specific research questions were:

1. What are the major environmental predictors that determine habitat suitability for each of 11 invasive weed species across the road network of Montana, USA?

2. What are the projected habitat suitability ranges of these species based on projected mid-century climate?

\section{Method}

\section{Study area and invasive species of interest}

The state of Montana is dominated by agriculture and wildlands. High altitude landscape is dominated by conifer forests, whereas valley bottoms and high plains are dominated by grassland, shrublands, and agriculture. Montana has an arid and semi-arid climate, which has been projected to increase with elevated future temperature (Whitlock et al. 2017; Adhikari and Hansen 2019). The study region is undergoing rapid intensification of human land uses in some areas and depopulation in other rural agricultural regions (Adhikari and Hansen 2018; Adhikari et al. 2019b).

Roadsides adjacent to the main highways and roads maintained by the Montana Department of Transportation (MDT) were inventoried (Fig. 1). The width of roadsides varies by road types (Isaacson et al. 2006): interstate rights-of-way are typically $79 \mathrm{~m}$ from fence-line to fence-line, with $0.9 \mathrm{~km}^{2}$ of non-roadway per $1.60 \mathrm{~km}$; primary highways are typically $49 \mathrm{~m}$ wide from fence-line to fence-line with $0.9 \mathrm{~km}^{2}$ of non-roadway per $1.6 \mathrm{~km}$; secondary highways and frontage roads are typically $37 \mathrm{~m}$ wide from fence-line to fence-line with $0.06 \mathrm{~km}^{2}$ of non-roadway per $1.6 \mathrm{~km}$. Roadsides were inventoried for 23 invasive species legally designated as noxious by the state of Montana. The occurrence of each invasive species was recorded for each $1.6 \mathrm{~km}$ (1 mile), using mile markers as section delineators. Data were collected by teams of two during the peak vegetative period (mid-June to midAugust); 30 counties were sampled in 2003, 18 in 2005, and 7 in 2006; one county was not surveyed. The sampling approach was validated by walking random sections and comparing with data taken while driving: the results were similar (Rew, unpublished). A total of $\sim 19,300 \mathrm{~km}$ of roadsides (primary roads, $4800 \mathrm{~km}$ and secondary roads, $\sim 14,200$ ) were inventoried.

Noxious weeds are classified into five classes based on management priorities (Montana State of Secretary (Table 1) (http://msuinvasiveplants.org/noxioussub.html). Twentythree species were observed, the 11 most abundant species with over 200 presence record were used for further analyses. These species are considered under the PRIORITY 2B class by the state of Montana. According to this class, these weed species are abundant in many counties across Montana, and management should be focused on eradication or containment in the area where their distribution is least abundant. The 11 species included are Cardaria draba (L.) Desv., Centaurea maculosa L., Cirsium arvense (L.) Scop., Convolvulus arvensis L., Cynoglossum officinale L., Euphorbia esula L., Hypericum perforatum L., Leucanthemum vulgare Lam., Linaria dalmatica (L.) Mill., Potentilla recta L., and Tanacetum vulgare L.(Table 1).

\section{Climatic and environmental predictors}

We used average monthly minimum and maximum temperature, precipitation, potential evapotranspiration (PET), vapor pressure deficit (VPD), relative humidity (RH), and solar radiation (SR) as climate predictors to project current distribution of these invasive species. These predictors were derived from Multivariate Adaptive Constructive Analogs (MACA) products at 4-km spatial resolution. The MACA products provide the data derived by a statistical downscaling method and calibrated with observed meteorological dataset (i.e., training dataset) to make compatible spatial patterns after correcting historical biases (Abatzoglou and Brown 2012). The 4-km spatial data was then statistically downscaled to 1-km spatial resolution. All the historic climate data were summarized as monthly average for the period of 1980-2006. In addition to the climatic variables, we used available soil water holding capacity (ASWHC) and percent sand (Miller and White 1998) as other environmental predictors. All the predictors considered initially are listed in Supplement. However, not all of these predictors were used in the modeling species distribution.

\section{Multicollinearity analysis}

Of the eighty-seven environmental predictors considered initially for constructing SDM, only a subset of them were saved for modeling by eliminating highly correlated variables. Highly collinear predictors do not uniquely contribute to the model, but such collinearity among predictors can be problematic when assessing significance of individual parameters. Therefore, we eliminated highly correlated predictors from the 
Fig. 1 Invasive weeds were inventoried along roadsides of major highways and roads in Montana, USA. A total of $19,000 \mathrm{~km}$ of roadsides: primary, $4800 \mathrm{~km}$ and secondary, $\sim 14,200$ were inventoried for the record of invasive weed species

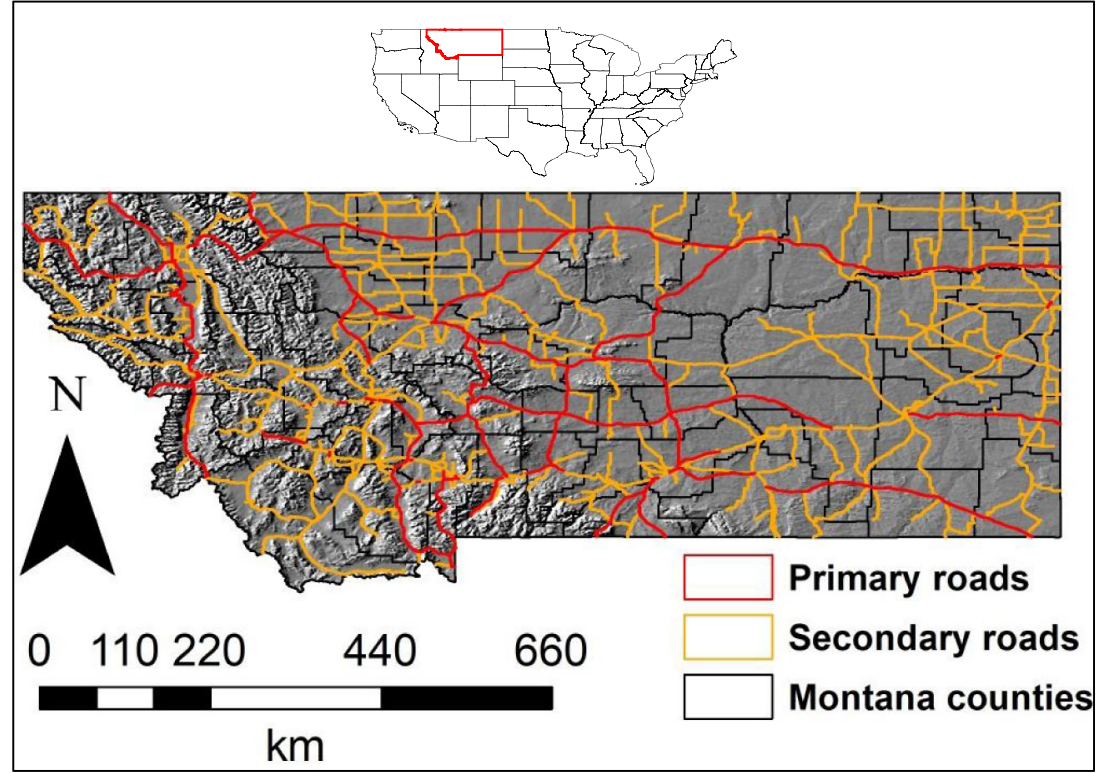

initial sets of environmental variables. Multicollinearity among predictors was assessed by evaluating cross- correlation among all variables using the Software for Assisted Habitat Modeling (SAHM) embedded in the

Table 1 Eleven invasive weed species from the Montana road network, their scientific and common names, and number of presence (observation) records. All species considered for this study are listed under noxious weed (PRIORITY 2B) in Montana

\begin{tabular}{|c|c|c|c|c|}
\hline Inventory species & Common name & Abbreviation & Number observations & Weed category \\
\hline Centaurea maculosa Lam. & Spotted knapweed & cema & 4542 & Priority 2B \\
\hline Cirsium arvense (L.) Scop. & Canada thistle & ciar & 4166 & Priority 2B \\
\hline Convolvulus arvensis L. & Field bindweed & coar & 2988 & Priority $2 \mathrm{~B}$ \\
\hline Cardaria draba (L.) Desv. & Whitetop & cadr & 1166 & Priority 2B \\
\hline Euphorbia esula L. & Leafy spurge & eues & 1074 & Priority 2B \\
\hline Cynoglossum officinale $\mathrm{L}$. & Houndstongue & cyof & 859 & Priority 2B \\
\hline Linaria dalmatica (L.) Mill. & Dalmation toadflax & lida & 816 & Priority 2B \\
\hline Leucanthemum vulgare Lam. & Oxeye daisy & levu & 733 & Priority 2B \\
\hline Tanacetum vulgare $\mathrm{L}$. & Common tansy & tavu & 680 & Priority 2B \\
\hline Hypericum perforatum $\mathrm{L}$. & St. John's wort & hype & 598 & Priority 2B \\
\hline Potentilla recta $\mathrm{L}$. & Sulfur cinquefoil & pore & 244 & Priority 2B \\
\hline Hieracium aurantiacum $\mathrm{L}$. & Orange hawkweed & hiau & 148 & Priority $2 \mathrm{~A}$ \\
\hline Rhaponticum repens (L.) Hidalgo & Russian knapwood & rhre & 139 & Priority 2B \\
\hline Ranunculus acris L. & Tall buttercup & raac & 115 & Priority 2A \\
\hline Crupina vulgaris Cass. & Common crupina & crvu & 86 & Delisted \\
\hline Centaurea diffusa Lam. & Diffuse knapwood & cedi & 60 & Priority $2 \mathrm{~B}$ \\
\hline Hieracium caespitosum Dumort. & Medow hawkweed & hica & 46 & Priority $2 \mathrm{~A}$ \\
\hline Senecio jacobaea L. & Tansy ragwort & seja & 8 & Priority $2 \mathrm{~A}$ \\
\hline Isatis tinctoria $\mathrm{L}$. & Dyers woad & isti & 7 & Priority $1 \mathrm{~A}$ \\
\hline Lythrum salicaria $\mathrm{L}$. & Purple loosestrife & lysa & 3 & Priority 1B \\
\hline Tamarix $\mathrm{L}$. & Tamarisk & - & 3 & Priority 2B \\
\hline Centaurea solstitialis L. & Yellow starthistle & ceso & 0 & Priority $1 \mathrm{~A}$ \\
\hline Chondrilla juncea $\mathrm{L}$. & Rush skeleton weed & chju & 0 & Priority 1B \\
\hline
\end{tabular}

Montana noxious weed list 2019: priority 1A: absent in the state; priority 1B: limited presence; priority 2A: common in isolated areas; priority 2B: abundant and widespread; priority 3: not noxious but regulated due to their potential for significant negative ecological and economic impacts. Source: (http://msuinvasiveplants.org/noxioussub.html) 
VisTrails scientific workflow management system (Morisette et al. 2013). During this analysis, when two variables had a Pearson's correlation coefficient, $r>0.70$, we retained only one of each pair of correlated variables for model development (Dormann et al. 2007) where the decision about which one to select was based on ecological knowledge of speciesenvironment relationship. Each species ended up with different subset of predictors once correlated variables were eliminated (see Table 2 for the final list of covariates used for habitat suitability modeling of each species).

\section{Future climate data}

To understand impacts of high carbon emission under climate, we adopted a climate change scenario with the same sets of future (2011 to 2040) environmental predictors as in current period but projected by general circulation models (GCMs). The scenario was generated from the experiments conducted under fifth assessment of Coupled Model Intercomparison Project Phase 5 (CMIP5) for the Intergovernmental Panel on Climate Change. The climate change scenario includes high representative concentrative pathway (RCP 8.5) from 2011 to 2040. The RCP 8.5 scenario represents the amount of anthropogenic forcing of $8.5 \mathrm{~W} / \mathrm{m}^{2}$ consistent with increases in atmospheric greenhouse gases at current rates (Moss et al. 2010). Climate predictors for future period from 2011 to 2040 were averaged from a warm and dry climate scenario predicted by CCSM4 GCM. The CCSM4 moderately captures overall spread of future projections of temperature and precipitation changes across the study area (Adhikari and Hansen 2019).

\section{Modeling approach}

Using the subsets of predictors in Table 2, we selected algorithms for six models within an ensemble framework to create consensus bioclimatic niche models of each invasive species using the Biomod2 software programmed in $\mathrm{R}$ environment (Thuiller et al. 2016). The consensus model for each species included generalized linear models (GLMs) (Austin et al. 1994), random forest (RF) (Prasad et al. 2006; Magness et al. 2008), multivariate adaptive regression spline (MARS) (Moisen and Frescino 2002), artificial neural network (ANN) (Olden et al. 2008), classification tree analysis (CTA) (Breiman et al. 1984), and flexible discriminant analysis (FDA) (Hastie et al. 1994). The ensemble model output considered the mean suitable value for each route.

Table 2 Relative importance of variables for each invasive weed species

\begin{tabular}{|c|c|c|c|c|c|c|c|c|c|c|c|c|c|c|c|c|c|c|c|c|c|}
\hline cema & imp. & ciar & imp. & coar & imp. & cyof & imp. & eues & imp. & hype & imp. & levu & imp. & lida & imp. & cadr & imp. & pore & imp. & $\operatorname{tavu}$ & imp. \\
\hline tmin_2 & 0.41 & sr_8 & 0.35 & tmax_3 & 0.29 & tmin_2 & 0.43 & vpd_12 & 0.45 & sr_6 & 0.73 & sr_6 & 0.43 & tmin _2 & 0.47 & pr 5 & 0.30 & $\operatorname{tmin} \_2$ & 0.64 & vpd_12 & 0.37 \\
\hline tmin_9 & 0.24 & tmin_2 & 0.35 & pr_7 & 0.28 & sr_7 & 0.26 & sr_6 & 0.33 & vpd_12 & 0.25 & vpd_12 & 0.27 & pr_9 & 0.27 & pr_9 & 0.26 & pr_12 & 0.30 & pr_10 & 0.33 \\
\hline vpd_12 & 0.13 & pr_8 & 0.29 & pr_8 & 0.20 & tmin_9 & 0.25 & $\mathrm{sr} \_8$ & 0.29 & sr_3 & 0.11 & pr_3 & 0.26 & pr_3 & 0.23 & sr_9 & 0.24 & $\mathrm{sr} \_6$ & 0.24 & tmax_3 & 0.20 \\
\hline pet_7 & 0.09 & pr_9 & 0.26 & sr_9 & 0.14 & pr_12 & 0.21 & sr_9 & 0.25 & $\operatorname{tmin} \_2$ & 0.11 & tmin_2 & 0.17 & vpd_12 & 0.16 & vpd_12 & 0.20 & sr_4 & 0.24 & rh_7 & 0.17 \\
\hline sr_ 7 & 0.06 & pr_3 & 0.22 & pet_7 & 0.13 & tmax_3 & 0.19 & pet_7 & 0.12 & sr_9 & 0.09 & rh_7 & 0.10 & pet_7 & 0.15 & sr_5 & 0.19 & rh_5 & 0.21 & pr_7 & 0.14 \\
\hline sr_9 & 0.06 & sr_7 & 0.21 & vpd_12 & 0.11 & sr_9 & 0.17 & sr_5 & 0.12 & sr_5 & 0.09 & pet_7 & 0.10 & pr_7 & 0.15 & pet_7 & 0.18 & pr_5 & 0.20 & sr_3 & 0.13 \\
\hline pr_7 & 0.06 & sr_6 & 0.18 & sr_8 & 0.11 & pr_8 & 0.16 & pr_7 & 0.11 & pr_7 & 0.08 & $\mathrm{sr} \_8$ & 0.09 & rh_5 & 0.12 & sr_8 & 0.16 & rh_7 & 0.19 & pet_7 & 0.08 \\
\hline sr_ 8 & 0.05 & tmin_9 & 0.17 & pr_5 & 0.10 & pr_7 & 0.14 & pr_5 & 0.10 & pr_10 & 0.07 & sr_4 & 0.09 & sr_7 & 0.12 & tmin_12 & 20.16 & sr_7 & 0.17 & sr_9 & 0.08 \\
\hline sr_5 & 0.05 & sr_9 & 0.16 & sr_5 & 0.08 & sr_8 & 0.12 & pr_8 & 0.10 & sr_7 & 0.07 & sr_7 & 0.09 & sr_8 & 0.12 & pr_3 & 0.15 & sr_9 & 0.15 & $\mathrm{sr} \_8$ & 0.08 \\
\hline pr_3 & 0.04 & pr_5 & 0.14 & pr_12 & 0.08 & $\mathrm{rh}_{-} 12$ & 0.11 & sr_7 & 0.10 & sr_8 & 0.07 & pr_5 & 0.07 & rh_7 & 0.12 & pr_8 & 0.15 & sr_8 & 0.14 & pr_5 & 0.07 \\
\hline pr_9 & 0.04 & rh_7 & 0.11 & sr_4 & 0.06 & pet_7 & 0.09 & pr_12 & 0.09 & tmax_1 & 0.06 & sr_9 & 0.07 & tmin_9 & 0.12 & tmax_3 & 0.14 & pet_7 & 0.13 & tmin_9 & 0.06 \\
\hline sr_4 & 0.03 & pr_6 & 0.11 & sr_7 & 0.06 & pr_9 & 0.08 & rh_5 & 0.08 & pet_7 & 0.04 & pr_7 & 0.06 & sr_9 & 0.11 & pr_7 & 0.12 & pr_7 & 0.12 & pr_9 & 0.06 \\
\hline pr_5 & 0.03 & rh_5 & 0.09 & pr_9 & 0.04 & pr_5 & 0.08 & sr_4 & 0.07 & pr_8 & 0.03 & tmin_9 & 0.05 & pr_5 & 0.10 & $\mathrm{rh} \_5$ & 0.09 & pet_2 & 0.09 & pr_8 & 0.04 \\
\hline \multirow[t]{4}{*}{ awh } & 0.01 & pr_7 & 0.08 & tmin_9 & 0.03 & rh_5 & 0.07 & tmin_9 & 0.06 & pr_5 & 0.03 & $\operatorname{tmax} \_2$ & 0.04 & pr_8 & 0.10 & tmin_9 & 0.04 & pr_8 & 0.08 & sr_5 & 0.03 \\
\hline & & awh & 0.08 & awh & 0.01 & sr_5 & 0.07 & pr_9 & 0.06 & tmin_9 & 0.03 & awh & 0.02 & sr_5 & 0.09 & awh & 0.02 & tmin_9 & 0.07 & awh & 0.01 \\
\hline & & sr_5 & 0.06 & & & rh_7 & 0.06 & $\operatorname{tmin} \_2$ & 0.05 & awh & 0.01 & & & awh & 0.03 & & & pr_9 & 0.06 & & \\
\hline & & pet_7 & 0.06 & & & awh & 0.02 & awh & 0.02 & & & & & & & & & awh & 0.01 & & \\
\hline
\end{tabular}

The number at the end of each variable represents the respective month (e.g., tmin 2: February minimum temperature; sr 7: July solar radiation) imp variable importance score, cema Centauria maculosa, coar Convolvulus arvensis, ciar Cirsium arvense, cyof Cynoglossum officinale, eues Euphorbia esula, hype Hypericum perforatum, cadr Cardaria draba, levu Leucanthemum vulgare, pore Potentilla recta, tavu Tanacetum vulgare, lida Linaria dalmatica, awh available soil water holding capacity, tmin minimum temperature, $v p d$ vapor pressure deficit, pet potential evapotranspiration, sr solar radiation, $p r$ precipitation, tmax maximum temperature 


\section{Model evaluation}

The accuracy of the model was assessed from the data generated by a split-sample. The data were randomly split in a ratio where $80 \%$ of data were used for model development and $20 \%$ data were used for model evaluation with 3 -fold crossvalidation. We used area under the curve (AUC) values of receiver operator characteristic (ROC) curves to assess the model performance. The model evaluation methods inherit different weights to multiple prediction errors such as omission, commission, or confusion. Models with the AUC value $<0.70$ is considered poor, $0.7-0.9$ considered moderate, and $>0.9$ considered a good model (Fielding and Bell 1997).

\section{Analysis}

We assessed AUC scores secured by the ensemble model to evaluate the model performance for each species. The study also assessed the relative influence of the predictors on habitat projections of each species. The model first projected probability of distribution of each species for the entire state of Montana. We then created 250-m buffer along both sides of the road network. Within 25-m buffer, we categorized probability or habitat suitability of each species into two categories, suitable habitat with a value $>0.51$, and unsuitable with a value $<0.51$. Results provided below are taken from the roadside data.

\section{Results}

During our study, we made total observations of 11,739 (presence and absence together) for each species. There were altogether 23,023 presence observations for 11 invasive weeds across road networks of State of Montana. Presence observations for each species are given in Table 1. After removing highly correlated variables, a total of 28 (14 to 17 predictors for each species) predictors were retained for constructing the species distribution models for 11 species (Table 2). Model ensemble output showed a moderate to excellent agreement in predicting observed distribution of the species with AUC value ranging from 0.77 to 0.96 (Table 3). The model accuracy for $H$. perforatum (0.96) and $L$. vulgare $(0.96)$ were the highest, and lowest for $C$. arvense (0.77), among the 11 modeled invasive weed species.

The influence of environmental predictors varied across the species. February minimum temperature was the most influential variable for the distribution of five species including C. maculosa, C. arvense, C. officinale, $L$. dalmatica, and $P$. recta. A wide range of monthly precipitation and December VPD explained the most variation in distribution of C. draba, E. esula, H. perforatum, L. vulgare, and T. vulgare. June solar radiation showed considerable influence on distribution of E. esula, $H$. perforatum, and $L$. vulgare. When considering the most influential variables, monthly minimum and maximum temperature, monthly precipitation, and solar radiation explained a greater variability on projected distribution of majority of species (Table 2).

Along 250-m buffered roadsides in Montana, USA, the model ensemble projected the widest current geographic distribution for $C$. arvense $\left(15,091 \mathrm{~km}^{2}\right)$ followed by C. maculosa $\left(14,988 \mathrm{~km}^{2}\right)$ and C. arvensis $\left(14,369 \mathrm{~km}^{2}\right)$ (Table 3, Fig. 2). The model ensemble projected the most restricted distributions of $H$. perforatum $\left(3590 \mathrm{~km}^{2}\right)$ followed by P. recta $\left(4229 \mathrm{~km}^{2}\right)$, and L. vulgare $\left(5160 \mathrm{~km}^{2}\right)$. The projected spatial distribution of other species ranged from 5491 to $9286 \mathrm{~km}^{2}$ (Table 3, Fig. 2).

Out of the 11 invasive weed species, the model ensemble projected expansion of habitat suitability of seven species along the 250-m buffered roadside in Montana, USA, by 2040 under RCP 8.5. The expansion of habitat suitability ranged from 5 to $647 \%$ under the high emission climate change scenario RCP 8.5 (Table 3, Figs. 3 and 4). When compared with current distribution, the model ensemble projected the greatest expansion, a six-fold increase in area infested, of $H$. perforatum. Potentilla recta showed 1.5-fold expansion of its habitat compared with the projected current habitat. The projected expansion of habitat suitability of other invasive weed species was lower, and ranged from 0.5 to $57 \%$. However, the model ensemble also projected a reduction in spatial distribution of four species in the future, including E. esula $(-88 \%)$ followed by C. maculosa $(-26 \%)$, C. draba (-13\%), and L. dalmatica (-11\%).

\section{Discussion}

Our study identified key climatic drivers affecting weed distribution and projected the habitat suitability of the 11 most abundant noxious invasive weed species across the major road network of Montana, USA, under current and future climate scenarios using an ensemble of models. The results highlight the species and roadside areas of the state requiring more detailed risk assessments on invasion of the 11 species listed as noxious weeds in Montana. Based on estimated AUC value, the ensemble model provided an accurate fit to the current distribution of weed species along roadsides of Montana. The impacts of climate change on future potential distribution of these invasive weeds are informative to weed managers. Out of 11 species, the model projected expansion of suitable habitat for seven species under projected climate change. Though, we projected habitat suitability of invasive weeds on the road networks, these species have invasion potential as source populations to invade (Endriss et al. 2018; McDougall et al. 2018) beyond the current projected distributions (Fig. 4), negatively impacting ecosystems, agriculture, and biodiversity. 
Table 3 AUC scores, current habitat, and future habitat suitability of 11 invasive weeds projected by ensemble models under RCP8.5 along road network of state of Montana for the year 2040. All species are listed under noxious weed (PRIORITY 2B) in Montana

\begin{tabular}{lcccc}
\hline Species & AUC & Current habitat $\left(\mathrm{km}^{2}\right)$ & Future habitat $\left(\mathrm{km}^{2}\right)$ & Change in habitat $(\%)$ \\
\hline Cardaria draba & 0.96 & 6,937 & 4,243 & -0.13 \\
Centaurea maculosa & 0.93 & 14,988 & 3,452 & -0.26 \\
Cirsium arvense & 0.91 & 15,091 & 11,264 & 0.47 \\
Convolvulus arvensis & 0.77 & 14,369 & 26,982 & 0.57 \\
Cynoglossum officinale & 0.88 & 7,348 & 25,698 & 0.21 \\
Euphorbia esula & 0.92 & 8,825 & 9,850 & -0.88 \\
Hypericum perforatum & 0.85 & 3,590 & 1,110 & 6.47 \\
Leucanthemum vulgare & 0.96 & 5,160 & 30,573 & 0.42 \\
Linaria dalmatica & 0.92 & 9,286 & 5,847 & -0.11 \\
Potentilla recta & 0.85 & 4,229 & 13,282 & 1.50 \\
Tanacetum vulgare & 0.89 & 5,491 & 2,058 & 0.05 \\
\hline
\end{tabular}

\section{Modeling results}

The results of habitat modeling under climate change provided information on changes in the potential distribution of the 11 invasive weeds. Overall, the model projected the expansion of suitable habitat for most of the species. In our study, $H$. perforatum was projected to have the greatest potential to expand extensively throughout the Montana road network but most expansively in southwest Montana, posing potential threats to agricultural sustainability and wildland ecosystems in that region. However, the model performance for observed distribution was in moderate agreement. $H$. perforatum is a perennial introduced species in North America which grows well along roadsides, abandoned fields, and overgrazed sites (Vilà et al. 2003; Maron et al. 2004; Vilà et al. 2005), but it currently has limited distribution in the state. Vilà et al. (2003) specified that current restricted distribution of $H$. perforatum is due to competitive exclusion from co-occurring species. Though less pronounced, other species such as C. arvense, $L$. vulgare, and P. recta were also projected to expand across the road network of Montana. Cirsium arvense was projected to spread throughout roadsides of central and eastern Montana, whereas P. recta was projected to expand throughout southern Montana along the road corridors.

Interestingly, our model ensemble projections based on the projected climate change scenario indicated a future contraction of habitat suitability of four species (C. maculosa, E. esula, C. draba, and L. dalmatica). However, factors other than climate may change and overcome the constraints placed on these species by changing climate alone. Our ensemble
Fig. 2 Projected current habitat range of eleven invasive species under current climate across roadsides in the state of Montana, USA

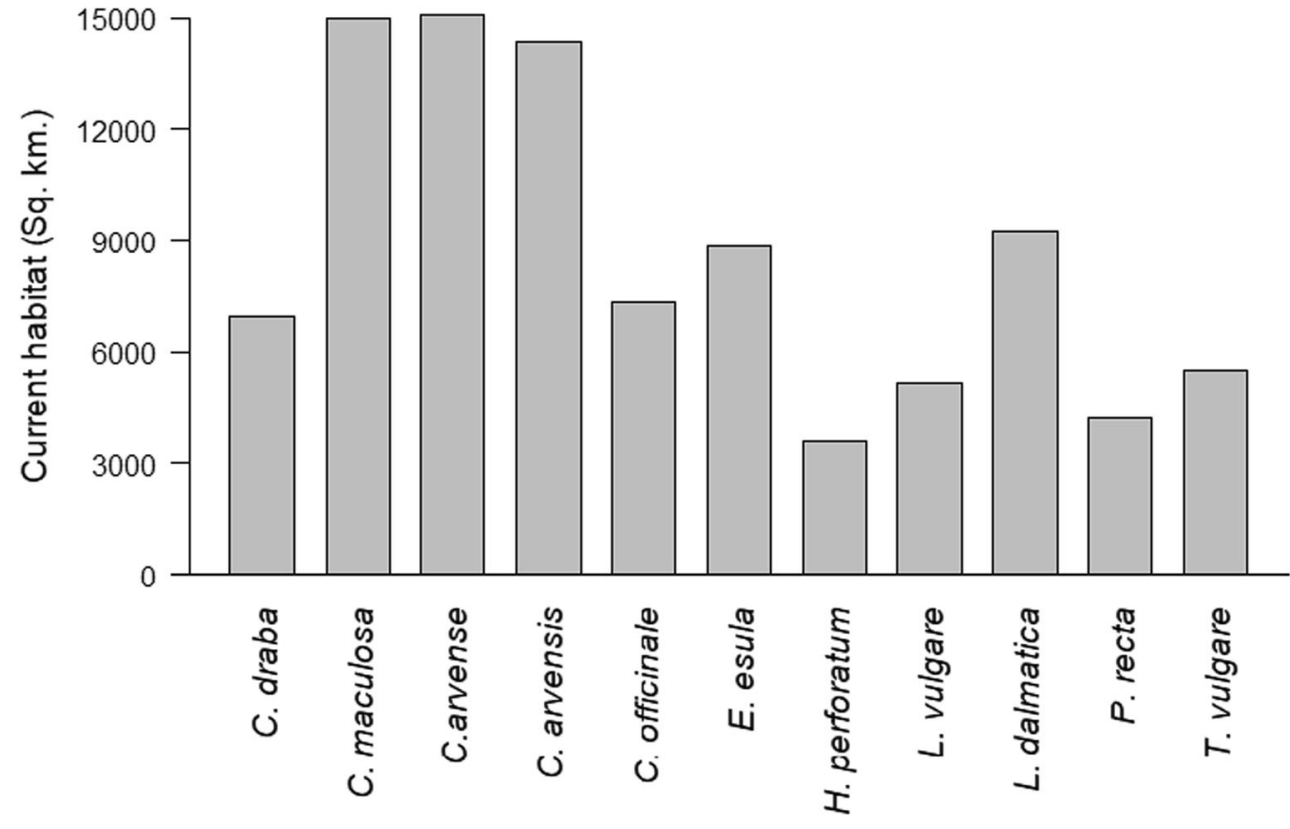


Fig. 3 Projected change in habitat range for eleven invasive weed species across the road networks of state of Montana, USA.

Suitable habitat of each species was projected for the year 2040 under RCP 8.5 climate change scenarios using climate predictors from CCSM4 GCM

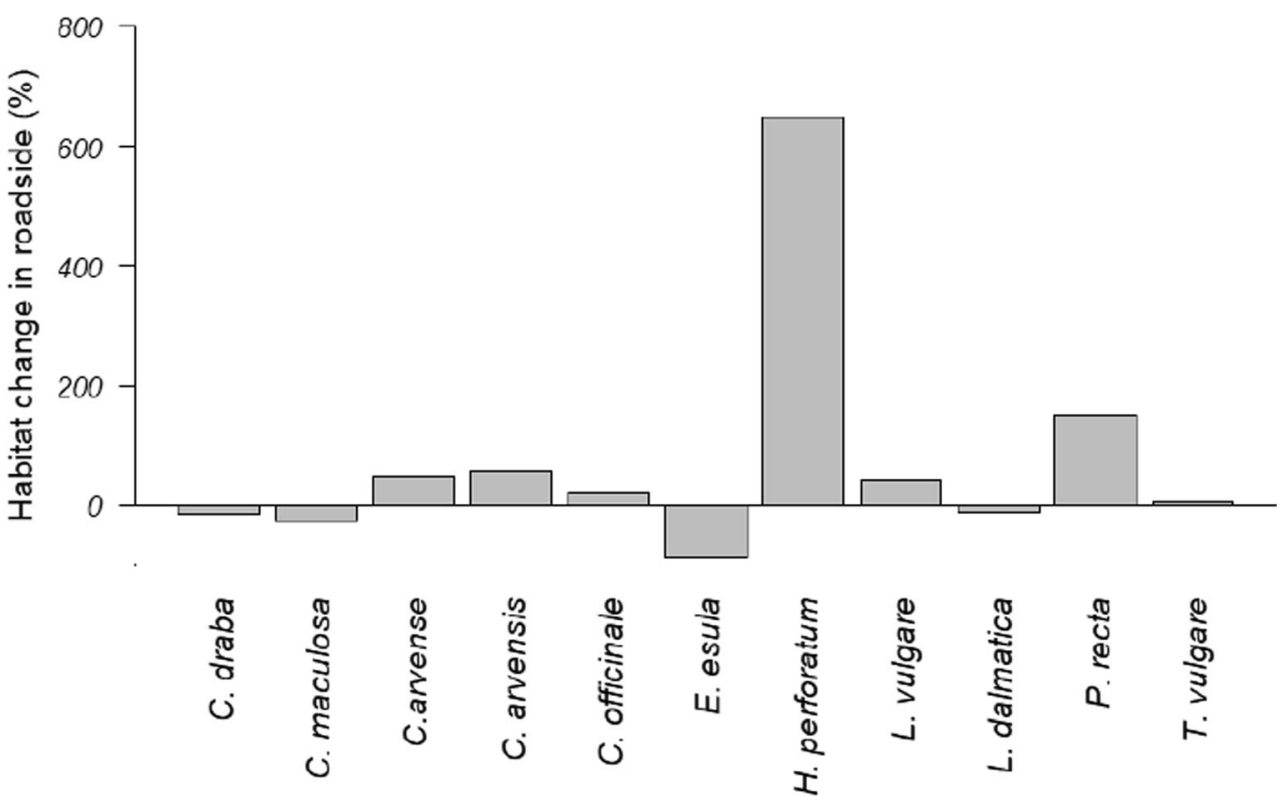

model projected considerable reduction in habitat suitability of E. esula along the Montana roadsides. It is uncertain if the habitat, which is projected to become unsuitable for some noxious weed species under climate change, could be occupied by ruderal native species or other weed species. Other invasive weeds, including $L$. vulgare, $C$. arvense, and C. arvensis, projected to increase with climate change may invade or expand in habitats abandoned by other invasive species in the future (Standish et al. 2008). Nonetheless, these findings are informative for resource allocation for weed management by considering areas where habitat suitability is projected to decrease/increase in the future.

Roads and vehicles are potential sources for introduction and spread of invasive plant species (Forman and Alexander 1998; Spellerberg 1998; Dostálek et al. 2016; Benedetti and Morelli 2017; Rew et al. 2018), faster than would occur by primary dispersal. Counties of Montana with high road density or busy highways are likely to be more invaded and be sources of further spread of invasive weed species regardless of climate change, as has been observed elsewhere (Vakhlamova et al. 2016). Since most of the Montana's roadsides are projected to become more infested by weeds, these sites call for detailed assessment and periodic monitoring. In addition, the risk assessment of invasive weeds should consider the projected response of weed species to changing climate (Crossman and Bass 2007; Crossman et al. 2011). However, not all species have equal potential to invade, and all habitats are not equally threatened by invasion to the same degree (Lonsdale 1999). The degree of invasion in a habitat depends on the traits (genetic variability) of invasive species, the phenotypic plasticity in the traits allowing response to climate change, and variability and other environmental variables defining a species recipient habitat as well as the propagule pressure with which invasive species are entering into the recipient habitat (Hulme 2007; Davidson et al. 2011; Rejmánek et al. 2013; Zhao et al. 2013).

Since our modeling approach was based on climatic factors, non-climatic factors such as biotic interactions and habitat types were not considered in this study which could have significant impacts on projecting habitat suitability. However, the modeling method applied in this study should capture the potential direction and distribution range and fundamental niches of these species under changing climate (Wharton and Kriticos 2004). Species do not necessarily distribute across the suitable environment as projected by models. Multiple reasons are responsible for restricting the species to occupy all the suitable habitats. Examples include geographical barriers, competition with other species, and limitation in dispersal ability of that species (Primack and Miao 1992; Kennedy et al. 2002; Levine et al. 2004; Byun and Lee 2017). The modeling approach provides general information about the environments to determine if that can be the potential habitat of a particular species.

\section{Importance of environmental predictors}

Along with road networks, the distribution of invasive species is heavily governed by relationships with environmental predictors (Weaver et al. 2012). This study showed that February minimum temperature and a range of mean monthly precipitation, solar radiation, and vapor pressure deficit variables account for the greatest variation in distribution of the 11 invasive species studied. However, a wider range of 

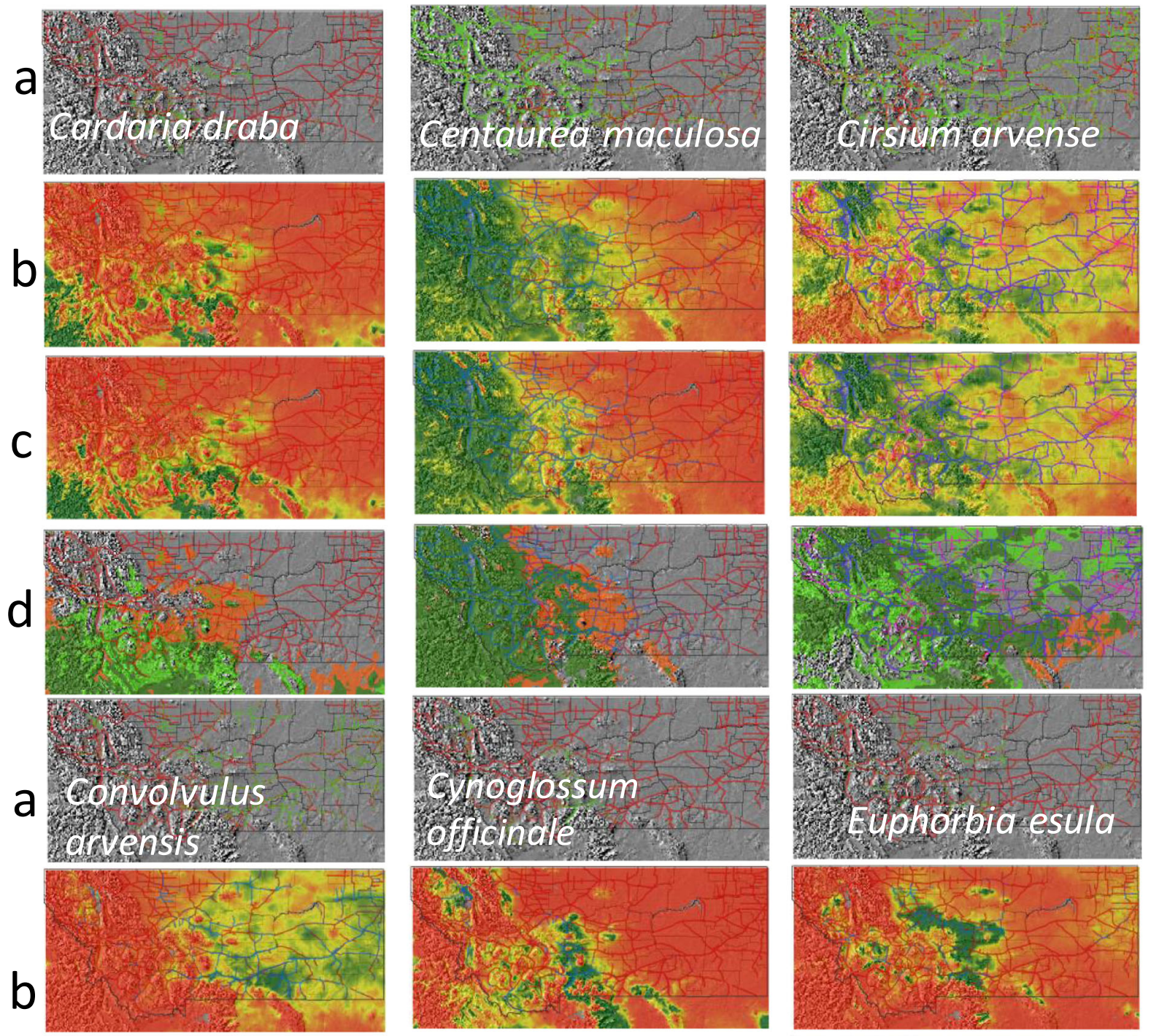

0.0

b
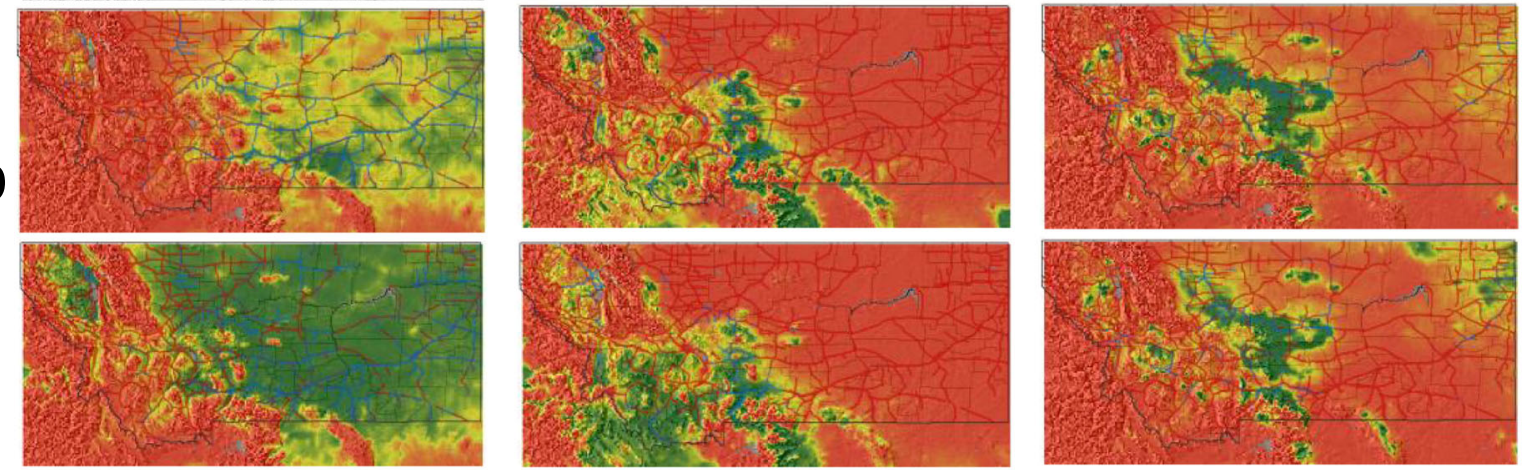

C
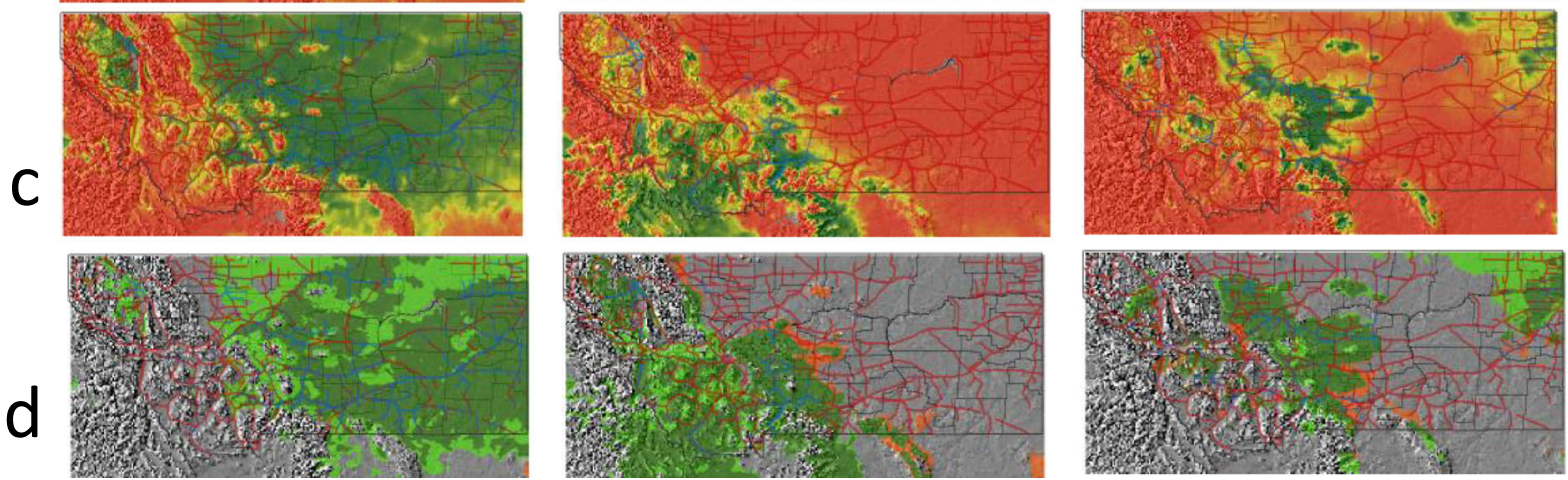

Fig. 4 Maps showing (a) presence (green color) and absence (red color) records of each species, (b) probability of current distribution under current climate, (c) probability of future distribution under climate change scenarios RCP 8.5 for the year 2040, and (d) habitat range changes, i.e., habitat deteriorating (loss), expanding habitat (gain), and

core habitat (stable or not change in the future) of each species under climate change scenario RCP8.5 for the year 2040. Blue and red colors along road networks in probability maps (b, c, and d) represent presence and absence record

environmental conditions have been found to determine the expansion of invasive species (Ward et al. 2008). The inherited phenotypic plasticity to tolerate the wider range of climate variability is often the important characteristics of

successful invasion (Sax et al. 2007). This may be due to the difference in collinearity between the predictors and adaptive traits of the invasive species. However, the extent of collinearity is contingent upon the species types, and geographical 
a

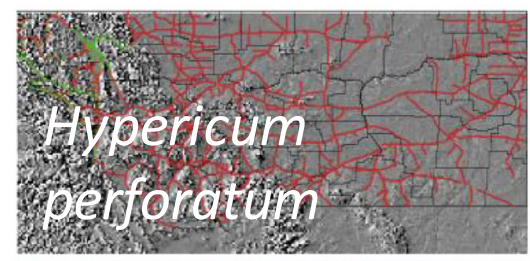

b

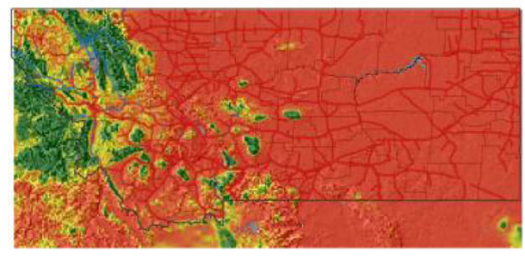

C
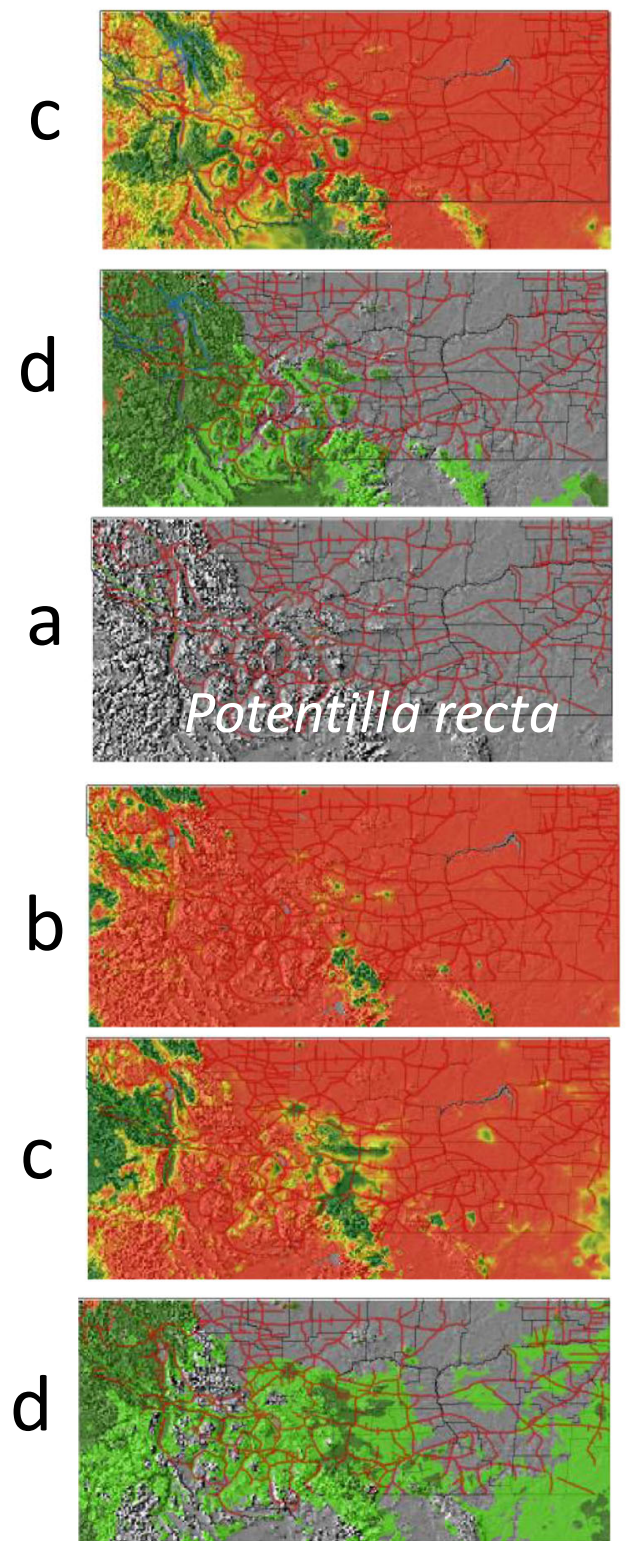

Fig. 4 (continued)
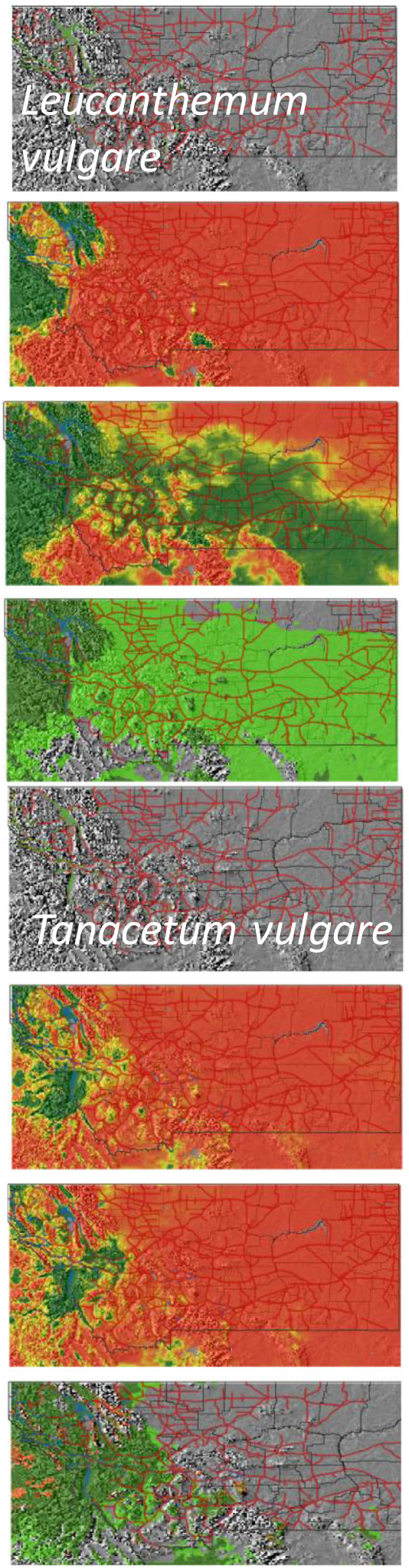
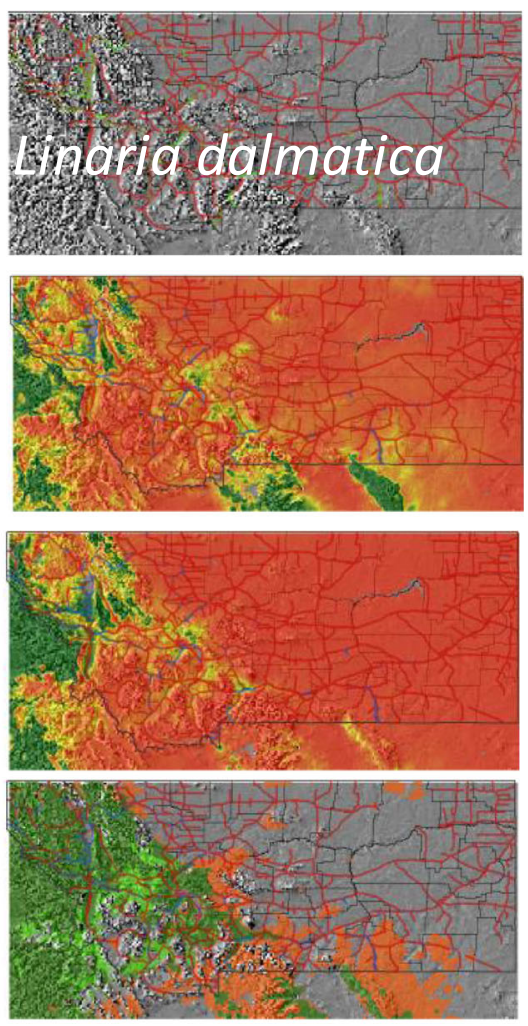

1

0.6

0.3

0.0

Deteriorating Expanding habitat Core habitat locations (Syphard and Franklin 2009; Acevedo et al. 2012). It is not surprising to see a broader range of environmental variables play a role in determining distribution of invasive species due to associated multiple limiting factors for their growth and distribution. 


\section{Limitation of the study}

The accuracy of the current climate scenario model for most of the species is very high, showing excellent model performance. However, high model performance has been reported to have some challenges (Mainali et al. 2015). One of the important challenges could be the metric of model performance that is only relevant to model training and testing sites. The evaluation metrics of model performance is irrelevant beyond the geographical space of model construction. Therefore, models with high accuracy have a tendency to project distribution of species far beyond the training area (Mainali et al. 2015). However, our results from the 250-m buffered area of road networks reduce the potential for exaggeration of the projected habitat in a given geographical landscape. In addition, a good fit of the model within the current habitat range does not necessarily reflect similar model performance in the future as the underlying relationship between habitat suitability of species and environmental predictors beyond climate could change over time (Porfirio et al. 2014). These two types of spatial and temporal caveats of SDMs show that the model may not perform as well as we expect, and our study does not rule out these challenges.

Another limitation of our study could be the study time which is around 15 years ago. It is possible that the occurrence of these species already changed (increase/decrease) due to climate, which has direct impacts on the species presence and absence records. However, since our modeling approach adopted the statistical method which has ability to project species presence or absence based on their correlation with environmental predictors, and because plant species movements are slow, we perceive this to be a limited issues and the patterns of our predictions would still be correct.

\section{Implication for the management}

The use of climate projection models linked with SDMs of 11 species presented here may be useful for their future management. The outcomes of this study can be used to inform decisions for resource allocations where risk of invasion increases and decreases under future climate. In addition, it can be adapted for management decisions to help preventing the spread of these weeds into new areas and to direct surveys to detect new populations. The results also give insight into prioritizing weed management initiatives in areas, by identifying which areas are currently at risk and will remain so in the future. Future studies should not only focus on predicting habitat distribution of more species that are either already known or unknown as invasive but also focus on identifying future invaders (Fournier et al. 2019) and invasibility of the ecosystems.

\section{Conclusion}

Our study suggests that modeling the climate-based habitat of noxious invasive weeds can constitute an important tool for projecting potential landscape scale distribution under future climate. The climate-driven SDM models of 11 invasive species were in agreement that future habitat and distribution of invasive weeds may change considerably; some may increase, while others may decrease in distribution along roads. Once the spatial distribution of target invasive plant populations is identified, the next step is monitoring to prioritize its management. Since all populations do not have equal potentials to increase at the same rate, measurements need to be taken to determine which populations in what types of environments are more or less invasive. Similarly, the efficacy of different management practices varies across environments. While it will never be possible to eliminate all invasive weed species or all populations of a specific noxious weed species, the information from modeling habitat suitability can aid in prioritizing the management of those populations that pose the greatest threat of increase in distribution and therefore to agriculture, wildlands, and roadsides.

Acknowledgments We appreciate constructive comments from two anonymous reviewers.

Funding information This research was partially funded by the Montana Noxious Weed Trust fund. LJR is supported by the National Institute of Food and Agriculture, US Department of Agriculture Hatch MONB00363.

\section{Compliance with ethical standards}

Conflict of interest The authors declare that they have no conflicts of interest.

Open Access This article is licensed under a Creative Commons Attribution 4.0 International License, which permits use, sharing, adaptation, distribution and reproduction in any medium or format, as long as you give appropriate credit to the original author(s) and the source, provide a link to the Creative Commons licence, and indicate if changes were made. The images or other third party material in this article are included in the article's Creative Commons licence, unless indicated otherwise in a credit line to the material. If material is not included in the article's Creative Commons licence and your intended use is not permitted by statutory regulation or exceeds the permitted use, you will need to obtain permission directly from the copyright holder. To view a copy of this licence, visit http://creativecommons.org/licenses/by/4.0/.

\section{References}

Abatzoglou JT, Brown TJ (2012) A comparison of statistical downscaling methods suited for wildfire applications. Int J Climatol 32:772-780. https://doi.org/10.1002/joc.2312 
Acevedo P, Jiménez-Valverde A, Lobo JM, Real R (2012) Delimiting the geographical background in species distribution modelling. J Biogeogr 39:1383-1390. https://doi.org/10.1111/ddi.12589

Adhikari A, Hansen AJ (2018) Land use change and habitat fragmentation of wildland ecosystems of the North Central United States. Landsc Urban Plan 177:196-216. https://doi.org/10.1016/j. landurbplan.2018.04.014

Adhikari A, Hansen AJ (2019) Climate and water balance change among public, private, and tribal lands within greater wild land ecosystems across North Central USA. Clim Chang 152:551-567. https://doi. org/10.1007/s10584-018-2351-7

Adhikari A, Mainali KP, Rangwala I, Hansen AJ (2019a) Various measures of potential evapotranspiration have species-specific impact on species distribution models. Ecol Model 414:108836. https://doi. org/10.1016/j.ecolmodel.2019.108836

Adhikari S, Adhikari A, Weaver DK, Bekkerman A, Menalled FD (2019b) Impacts of agricultural management systems on biodiversity and ecosystem services in highly simplified dryland landscapes. Sustainability 11:3223. https://doi.org/10.3390/su11113223

Austin MP, Nicholls AO, Doherty MD, Meyers JA (1994) Determining species response functions to an environmental gradient by means of a $\beta$-function. J Veg Sci 5:215-228. https://doi.org/10.2307/3236167

Bellard C, Cassey P, Blackburn TM (2016) Alien species as a driver of recent extinctions. Biol Lett 12:20150623. https://doi.org/10.1098/ rsbl.2015.0623

Benedetti Y, Morelli F (2017) Spatial mismatch analysis among hotspots of alien plant species, road and railway networks in Germany and Austria. PLoS One 12:e0183691. https://doi.org/10.1371/journal. pone. 0183691

Breiman L, Friedman J, Stone CJ, Olshen RA (1984) Classification and regression trees. Chapman and Hall/ CRC press, London

Byun C, Lee EJ (2017) Ecological application of biotic resistance to control the invasion of an invasive plant, Ageratina altissima. Ecol Evol 7:2181-2192. https://doi.org/10.1002/ece3.2799

Crossman ND, Bass DA (2007) Application of common predictive habitat techniques for post-border weed risk management. Divers Distrib 14:213-224. https://doi.org/10.1111/j.1472-4642.2007. 00436.x

Crossman ND, Bryan BA, Cooke DA (2011) An invasive plant and climate change threat index for weed risk management: integrating habitat distribution pattern and dispersal process. Ecol Indic 11:183198. https://doi.org/10.1016/j.ecolind.2008.10.011

D'Antonio CM, Vitousek PM (1992) Biological invasions by exotic grasses, the grass/fire cycle, and global change. Annu Rev Ecol Syst 23:63-87. https://doi.org/10.1146/annurev.es.23.110192. 000431

Davidson AM, Jennions M, Nicotra AB (2011) Do invasive species show higher phenotypic plasticity than native species and, if so, is it adaptive? A meta-analysis. Ecol Lett 14:419-431. https://doi.org/10. 1111/j.1461-0248.2011.01596.x

Dormann CF, Mcpherson JM, Araújo MB, Bivand R, Bolliger J, Carl G, Davies RG, Hirzel A, Jetz W, Daniel Kissling W, Kühn I, Ohlemüller R, Peres-Neto PR, Reineking B, Schröder B, Schurr FM, Wilson R (2007) Methods to account for spatial autocorrelation in the analysis of species distributional data: a review. Ecography 30: 609-628. https://doi.org/10.1111/j.2007.0906-7590.05171.x

Dostálek J, Frantík T, Šilarová V (2016) Changes in the distribution of alien plants along roadsides in relation to adjacent land use over the course of 40 years. Plant Biosyst 150:442-448. https://doi.org/10. 1080/11263504.2014.986244

Elith J, Graham CH, Anderson RP, Dudík M, Ferrier S, Guisan A, Hijmans RJ, Huettmann F, Leathwick JR, Lehmann A (2006) Novel methods improve prediction of species' distributions from occurrence data. Ecography 29:129-151. https://doi.org/10.1111/j. 2006.0906-7590.04596.x
Endriss SB, Alba C, Norton AP, Pyšek P, Hufbauer RA (2018) Breakdown of a geographic cline explains high performance of introduced populations of a weedy invader. J Ecol 106:699-713. https://doi.org/10.1111/j.2006.0906-7590.04596.x

Fielding AH, Bell JF (1997) A review of methods for the assessment of prediction errors in conservation presence/absence models. Environ Conserv 24:38-49. https://doi.org/10.1017/S0376892997000088

Forman RTT, Alexander LE (1998) Roads and their major ecological effects. Annu Rev Ecol Syst 29:207-231. https://doi.org/10.1111/ 1365-2745.12845

Fournier A, Penone C, Pennino MG, Courchamp F (2019) Predicting future invaders and future invasions. PNAS 16:7905-7910. https:// doi.org/10.1073/pnas.1803456116

Franklin J (2013) Species distribution models in conservation biogeography: developments and challenges. Divers Distrib 19:1217-1223. https://doi.org/10.1111/ddi.12125

Fridley JD, Stachowicz JJ, Naeem S, Sax DF, Seabloom EW, Smith MD, Stohlgren TJ, Tilman D, Holle BV (2007) The invasion paradox: reconciling pattern and process in species invasions. Ecology 88:317. https://doi.org/10.1890/0012-9658(2007)88[3:tiprpa]2.0.co;2

Gelbard JL, Belnap J (2003) Roads as conduits for exotic plant invasions in a semiarid landscape. Conserv Biol 17:420-432. https://doi.org/ 10.1046/j.1523-1739.2003.01408.x

Guisan A, Thuiller W (2005) Predicting species distribution: offering more than simple habitat models. Ecol Lett 8:993-1009. https:// doi.org/10.1111/j.1461-0248.2005.00792.x

Hansen AJ, Phillips LB (2015) Which tree species and biome types are most vulnerable to climate change in the US Northern Rocky Mountains? For Ecol Manag 338:68-83. https://doi.org/10.1016/j. foreco.2014.11.008

Hastie T, Tibshirani R, Buja A (1994) Flexible discriminant analysis by optimal scoring. J Am Stat Assoc 89:1255-1270. https://doi.org/10. 1080/01621459.1994.10476866

Hobbins RJ, Huenneke LF (1992) Disturbance, diversity, and invasion: implications for conservation. Conserv Biol 6:324-337. https://doi. org/10.2307/2386033

Hulme PE (2007) Phenotypic plasticity and plant invasions: is it all jack? Funct Ecol 22:3-7. https://doi.org/10.1111/j.1365-2435.2007.01369

Huston MA (2004) Management strategies for plant invasions: manipulating productivity, disturbance, and competition. Divers Distrib 10: 167-178. https://doi.org/10.1111/j.1366-9516.2004.00083.x

Isaacson Z, Repath CF, Dougher FL, Rew LJ (2006) Inventory and probability of occurrence maps for state listed noxious weed species. Montana State University, Bozeman, p 59

Kennedy TA, Naeem S, Howe KM, Knops JMH, Tilman D, Reich P (2002) Biodiversity as a barrier to ecological invasion. Nature 417: 636-638. https://doi.org/10.1038/nature00776

Levine JM, Adler PB, Yelenik SG (2004) A meta-analysis of biotic resistance to exotic plant invasions. Ecol Lett 7:975-989. https://doi. org/10.1111/j.1461-0248.2004.00657.x

Lonsdale WM (1999) Global patterns of plant invasions and the concept of invasibility. Ecology 80:1522-1536. https://doi.org/10.2307/ 176544

Lugo AE, Gucinski H (2000) Function, effects, and management of forest roads. For Ecol Manag 133:249-262. https://doi.org/10.1016/ s0378-1127(99)00237-6

Magness DR, Huettmann F, Morton JM (2008) Using random forests to provide predicted species distribution maps as a metric for ecological inventory and monitoring programs. In: Smolinski T, Milanova M, Hassanien AE (eds) Applications of computational intelligence in biology. Springer, Berlin, pp 209-229

Mainali KP, Warren DL, Dhileepan K, McConnachie A, Strathie L, Hassan G, Karki D, Shrestha BB, Parmesan C (2015) Projecting future expansion of invasive species: comparing and improving methodologies for species distribution modeling. Glob Chang Biol 21:4464-4480. https://doi.org/10.1111/gcb.13038 
Maron JL, Vilà M, Bommarco R, Elmendorf S, Beardsley P (2004) Rapid evolution of an invasive plant. Ecol Monogr 74:261-280. https:// doi.org/10.1890/03-4027

Maxwell BD, Lehnhoff E, Rew LJ (2009) The rationale for monitoring invasive plant populations as a crucial step for management. Invasive Plant Sci Manag 2:1-9. https://doi.org/10.1614/ipsm-07054.1

McDougall KL, Lembrechts J, Rew LJ, Haider S, Cavieres LA, Kueffer C, Milbau A, Naylor BJ, Nuñez MA, Pauchard A, Seipel T, Speziale KL, Wright GT, Alexander JM (2018) Running off the road: roadside non-native plants invading mountain vegetation. Biol Invasions 20:3461-3473. https://doi.org/10.1007/s10530-018-1787-z

Miller DA, White RA (1998) A conterminous United States multilayer soil characteristics dataset for regional climate and hydrology modeling. Earth Interact 2:1-26. https://doi.org/10.1175/10873562(1998)002<0001:ACUSMS>2.3.CO;2

MISAC (2016) Governor's summit on invasive species. Montana Invasive Species Advisory Council. The Montana Department of Natural Resources and Conservation. http://dnrc.mt.gov/divisions/ cardd/docs/misac-docs/montanaissummit_april2016-final.pdf. Accessed 10 April 2019

Moisen GG, Frescino TS (2002) Comparing five modelling techniques for predicting forest characteristics. Ecol Model 157:209-225. https://doi.org/10.1016/s0304-3800(02)00197-7

Mooney HA, Cleland EE (2001) The evolutionary impact of invasive species. PNAS 98:5446-5451. https://doi.org/10.1073/pnas. 091093398

Morisette JT, Jarnevich CS, Holcombe TR, Talbert CB, Ignizio D, Talbert MK, Silva C, Koop D, Swanson A, Young NE (2013) VisTrails SAHM: visualization and workflow management for species habitat modeling. Ecography 36:129-135. https://doi.org/10.1111/j.16000587.2012.07815.x

Moss RH, Edmonds JA, Hibbard KA, Manning MR, Rose SK, Van Vuuren DP, Carter TR, Emori S, Kainuma M, Kram T, Meehl GA, Mitchell JFB, Nakicenovic N, Riahi K, Smith SJ, Stouffer RJ, Thomson AM, Weyant JP, Wilbanks TJ (2010) The next generation of scenarios for climate change research and assessment. Nature 463:747-756. https://doi.org/10.1038/nature08823

Olden JD, Lawler JJ, Poff NL (2008) Machine learning methods without tears: a primer for ecologists. Q Rev Biol 83:171-193. https://doi. org/10.1086/587826

Pauchard A, Alaback PB, Edlund E (2003) Plant invasions in protected areas at multiple scales: Linaria vulgaris (Scrophulariaceae) in the West Yellowstone area. West N Am Nat 63:416-428. https://doi.org/ 10.2307/41717316

Pimentel D, Zuniga R, Morrison D (2005) Update on the environmental and economic costs associated with alien-invasive species in the United States. Ecol Econ 52:273-288. https://doi.org/10.1016/j. ecolecon.2004.10.002

Porfirio LL, Harris RM, Lefroy EC, Hugh S, Gould SF, Lee G, Bindoff NL, Mackey B (2014) Improving the use of species distribution models in conservation planning and management under climate change. PLoS One 9:e113749. https://doi.org/10.1371/journal. pone. 0113749

Prasad AM, Iverson LR, Liaw A (2006) Newer classification and regression tree techniques: bagging and random forests for ecological prediction. Ecosystems 9:181-199. https://doi.org/10.1007/ s10021-005-0054-1

Primack RB, Miao SL (1992) Dispersal can limit local plant distribution. Conserv Biol 6:513-519. https://doi.org/10.1046/j.1523-1739.1992. 06040513.x

Rejmánek M, Pitcairn M (2002) When is eradication of exotic pest plants a realistic goal? In:Veitch D, Clout $M$ (ed) Turning the tide: the eradication of invasive species. SSC Invasive Species Specialist Group. IUCN, Gland/Cambridge, pp 249-253
Rejmánek M, Richardson DM, Pyšek P (2013) Plant invasions and invasibility of plant communities. In: van der Maarel E (ed) Vegetation ecology. John Wiley and Sons, Oxford, pp 387-424

Rew LJ, Maxwell BD, Aspinall R (2005) Predicting the occurrence of nonindigenous species using environmental and remotely sensed data. Weed Sci 53:236-241. https://doi.org/10.1614/WS-04-097R

Rew LJ, Lehnhoff EA, Maxwell BD (2007) Non-indigenous species management using a population prioritization framework. Can J Plant Sci 87:1029-1036. https://doi.org/10.4141/cjps07121

Rew LJ, Brummer TJ, Pollnac FW, Larson CD, Taylor KT, Taper ML, Fleming JD, Balbach HE (2018) Hitching a ride: seed accrual rates on different types of vehicles. J Environ Manag 206:547-555. https://doi.org/10.1016/j.jenvman.2017.10.060

Sax D, Stachowicz J, Brown J, Bruno J, Dawson M, Gaines S, Grosberg R, Hastings A, Holt R, Mayfield M (2007) Ecological and evolutionary insights from species invasions. Trends Ecol Evol 22:465471. https://doi.org/10.1016/j.tree.2007.06.009

Skurski TC, Rew LJ, Maxwell BD (2014) Mechanisms underlying nonindigenous plant impacts: a review of recent experimental research. Invasive Plant Sci Manag 7:432-444. https://doi.org/10.1614/ IPSM-D-13-00099.1

Spellerberg I (1998) Ecological effects of roads and traffic: a literature review. Glob Ecol Biogeogr 7:317-333. https://doi.org/10.1046/j. 1466-822x.1998.00308.x

Standish RJ, Cramer VA, Hobbs RJ (2008) Land-use legacy and the persistence of invasive Avena barbata on abandoned farmland. J Appl Ecol 45:1576-1583. https://doi.org/10.1111/j.1365-2664. 2008.01558.x

Syphard AD, Franklin J (2009) Differences in spatial predictions among species distribution modeling methods vary with species traits and environmental predictors. Ecography 32:907-918. https://doi.org/ 10.1111/j.1600-0587.2009.05883.x

Thuiller W, Georges D, Engler R (2016) Biomod2: ensemble platform for species distribution modeling. R package version 3.1. https://cran.rproject.org/web/packages/biomod2/. Accessed 25 March 2019

Tikka PM, Högmander H, Koski PS (2001) Road and railway verges serve as dispersal corridors for grassland plants. Landsc Ecol 16: 659-666. https://doi.org/10.1023/A:1013120529382

Vakhlamova T, Rusterholz H-P, Kanibolotskaya Y, Baur B (2016) Effects of road type and urbanization on the diversity and abundance of alien species in roadside verges in Western Siberia. Plant Ecol 217:241-252. https://doi.org/10.1007/s11258-016-0565-1

Van Kleunen M, Dawson W, Essl F, Pergl J, Winter M, Weber E, Kreft H, Weigelt P, Kartesz J, Nishino M, Antonova LA, Barcelona JF, Cabezas FJ, Cárdenas D, Cárdenas-Toro J, Castaño N, Chacón E, Chatelain C, Ebel AL, Figueiredo E, Fuentes N, Groom QJ, Henderson L, Inderjit KA, Masciadri S, Meerman J, Morozova O, Moser D, Nickrent DL, Patzelt A, Pelser PB, Baptiste MP, Poopath M, Schulze M, Seebens H, Shu W-S, Thomas J, Velayos M, Wieringa JJ, Pyšek P (2015) Global exchange and accumulation of non-native plants. Nature 525:100-103. https://doi.org/10.1038/ nature 14910

Veldman JW, Putz FE (2010) Long-distance dispersal of invasive grasses by logging vehicles in a tropical dry forest. Biotropica 42:697-703. https://doi.org/10.1111/j.1744-7429.2010.00647.x

Vilà M, Gómez A, Maron JL (2003) Are alien plants more competitive than their native conspecifics? A test using Hypericum perforatum L. Oecologia 137:211-215. https://doi.org/10.1007/s00442-003$1342-0$

Vilà M, Maron JL, Marco L (2005) Evidence for the enemy release hypothesis in Hypericum perforatum. Oecologia 142:474-479. https://doi.org/10.1007/s00442-004-1731-z

Vitousek PM, Mooney HA, Lubchenco J, Melillo JM (1997) Human domination of Earth's ecosystems. Science 277:494-499. https:// doi.org/10.1126/science.277.5325.494 
Walker B, Steffen W (1997) An overview of the implications of global change for natural and managed terrestrial ecosystems. Conserv Ecol 1:1-17 https://www.jstor.org/stable/26271662

Ward SM, Gaskin JF, Wilson LM (2008) Ecological genetics of plant invasion: what do we know? Invasive Plant Sci Manag 1:98-109. https://doi.org/10.1614/ipsm-07-022.1

Weaver JE, Conway TM, Fortin M-J (2012) An invasive species' relationship with environmental variables changes across multiple spatial scales. Landsc Ecol 27:1351-1362. https://doi.org/10.1007/ s10980-012-9786-4

Wharton TN, Kriticos DJ (2004) The fundamental and realized niche of the Monterey Pine aphid, Essigella californica (Essig) (Hemiptera: Aphididae): implications for managing softwood plantations in Australia. Divers Distrib 10:253-262. https://doi.org/10.1111/j. 1366-9516.2004.00090.x

Whitlock C, Cross W, Maxwell B, Silverman N, Wade A (2017) Montana climate assessment. Montana Institute on Ecosystem, Bozeman, pp 318. https://doi.org/10.15788/m2ww8w
Williams M, Zalasiewicz J, Haff PC, Barnosky AD, Ellis EC (2015) The Anthropocene biosphere. Anthropol Rev 2:196-219. https://doi.org/ 10.1177/2053019615591020

Wilson JRU, Dormontt EE, Prentis PJ, Lowe AJ, Richardson DM (2009) Something in the way you move: dispersal pathways affect invasion success. Trends Ecol Evol 24:136-144. https://doi.org/10.1016/j. tree.2008.10.007

Zhao J, Solís-Montero L, Lou A, Vallejo-Marín M (2013) Population structure and genetic diversity of native and invasive populations of Solanum rostratum (Solanaceae). PLoS One 8:e79807. https:// doi.org/10.1371/journal.pone.0079807

Publisher's note Springer Nature remains neutral with regard to jurisdictional claims in published maps and institutional affiliations. 